ADDIN, Volume 11, Number 2, August 2017

\title{
THE LEADERSHIP OF THE HEAD
}

OF MADRASAH IN ESTABLISHING COMMUNICATION WITH STAKEHOLDER

\author{
Nadhirin \\ STAIN Kudus, Central Java, Indonesia \\ nadhirin072@gmail.com
}

\section{Abstract}

Educational leadership in madrasab is one of education management functions. Madrasab is a formal religious education institution which provide educational services to the public. The quality of education in madrasah can be known one of them through the performance of madrasah leadership and vice versa. This research focused on madrasah leadership in building communication with stakeholder based on Sunnah Prophet Muhammad saw. This research uses qualitative approach with post-posivistic and phenomenology paradigm with multicase design. The findings empirically in communication the head of madrasah leadership in establishing communication with sakeholders is: (1) to establish cooperation relationship with stakeholders element; (2) silaturrabim structured activities; (3) into the motor changes madrasah progress; (4) spiritual orientation and social capital to achieve financial and human capital; (5) together work based on the principle of expediency; (6) taboo to discuss about salary and position and embarrassment show property and property ownership; (7) position is trust and not purpose; (8) firmly in giving sanction; (8) supervision of madrasah culture background; (9) time 
and work discipline; (10) build relationships with graduates through programmed activities.

Keywords: Leadership, Communication, Madrasah, Stakeholder.

\section{Abstrak}

KEPEMIMPINAN KEPALA MADRASAH DALAM MEMBANGUN KOMUNIKASI DENGAN STAKEHOLDER. Kepemimpinan pendidikan di madrasah merupakan salab satu fungsi manajemen pendidikan. Madrasab adalah institusi pendidikan formal keagamaan yang memberikan pelayanan pendidikan kepada masyarakat. Kualitas pendidikan di madrasah dapat diketahui salah satunya melalui kinerja kepemimpinan madrasah dan sebaliknya. Penelitian ini difokuskan pada kepemimpinan madrasah dalam membangun komunikasi dengan stakeholders berdasarkan Sunnab Nabi Mubammad saw. Penelitian ini menggunakan pendekatan kualitatif dengan paradigma post-posivistik dan fenomenologi dengan desain multicase. Temuan penelitian kepemimpinan komunikasi kepala madrasah dalam membangun komunikasi dengan sakeholders adalab: (1) membangun bubungan kerja sama dengan unsur stakeholders; (2) kegiatan silaturrabim terstruktur; (3) menjadi motor perubahan kemajuan madrasab; (4) orientasi spiritual dan social capital untuk mencapai financial dan buman capital; (5) bersama bekerja berlandaskan prinsip kemanfaatan; (6) tabu berdiskusi tentang gaji dan jabatan dan malu menunjukekan kekayaan dan harta kepemilikan; (7) jabatan adalah amanah dan bukan tujuan; (8) tegas dalam memberikan sanksi; (8) supervisi berlatar budaya madrasah; (9) disiplin waktu dan pekerjaan; (10) membangun bubungan dengan alumni melalui kegiatan terprogram.

Kata Kunci: Kepemimpinan, Komunikasi, Madrasah, Stakeholder.

\section{A. Introduction}

Educational management is a planned and programmed activity to utilize and empower all educational resources for 
the realization of quality, effective, efficient, and accountable education services. Quality education and able to answer the needs and demands of the times needed professional management. All stakeholders i.e. the school, community, and government should be synergized for the realization of the ideals of education. Without cooperation from all parties, quality education is difficult to realize. ${ }^{1}$

Mulyasa defines, madrasah as a religious-based formal education institution that organizes educational services for the wider community. The basic purpose of education in the madrasah for the community is to provide public and religious education services for the community. Making quality madrasahs is a shared responsibility between government, society and education providers. All interested parties are united and synergize to support the realization of the ideals of madrasah, that is to realize the universe education, the inner, the body of spiritual, the happiness of the world and the hereafter. ${ }^{2}$

The Law of the National Education System Number 20 of 2003 provides equal attention to all education providers, including private Madrasah madrasah education is one of the non-government based educational institutions whose contribution to society is considerable. Institution of madrasah education has various channels, both formal and informal. Formal madrasahs have levels such as Madrasah Ibtidaiyah (MI), Madrasah Tsanawiyah (MTs), and Madrasah Aliyah (MA). Non-formal madrasahs are dayah and pesantren. ${ }^{3}$

${ }^{1}$ Mulyadi, Kepemimpinan Kepala Madrasah dalam Mengembangkan Budaya Mutu (Jakarta: Badan Litbang dan Diklat Kementerian Agama RI, 2010), 23.

${ }^{2}$ Mulyasa, Manajemen dan Kepemimpinan Kepala Madrasab (Jakarta: Bumi Aksara, 2002), 75.

${ }^{3}$ Undang-Undang Republik Indonesia Nomor 20 Tahun 2003 Tentang Sistem Pendidikan Nasional, http://www.hukum.unsrat.ac.id, PDF, accessed at 
Komariah explained that leadership have a considerable influence on the performance of the organization so rational when the low quality of education one of them due to the performance of the leadership that can not adjust to the change and also not able to make the educational strategy adaptable to change. ${ }^{4}$ One of the leadership functions is communication. Effective communication is crucial to the performance of leadership. Successful leadership is largely determined by the leader's communication style. As good as any vision of leadership without accompanied by proper communication function, then the vision is just a beautiful dream of educational institutions that never materialized. This implies that the function of communication is crucial in leadership.

Among educational leaders of varying degrees and grades, the head of madrasah is one of the educational leaders responsible for the implementation of the madrasah education program. Achievement of educational goals depends on the skills and wisdom of the head of madrasah as one of the educational leaders. This is because the head of madrasah is an official in a madrasah organization that is in charge of organizing all organizational resources and working with teachers in educating students to achieve higher quality, credible, and relevant educational objectives. Leadership activities of the head of madrasah in addition to following government regulations and education policies, the head of madrasah also has a strategic role and position in managing and madrasah. Progress and retreat the quality of the madrasah is concerned leadership quality of the head of madrasah. According Mulyadi, the head of madrasah

Oktober 14, 2013.

${ }^{4}$ A. Komariah and T. Cepi, Visionary Leadership: Menuju Sekolah Efektif (Jakarta: Bumi Aksara, 2005), 80. 
is the key to school success in making changes, so that activities improve and improve the program and learning process in school mostly lies in the leadership of the head of madrasah. ${ }^{5}$

Communication leadership of the head of madrasah has a very important role in realizing the ideals of madrasah. Every organization, not to mention educational institutions also have a variety of activities and provisions, mechanisms, procedures, and regulations that involve a variety of complex resources that exist. Educational resources will have a maximum role and function if managed with professional leadership.

In downtown Kudus, Central Java there are many education institutions in Madrasah Aliyah level, among them are MA TBS, MA Qudsiyah, and MA NU Banat. The three Madrasah Aliyah are formal educational institutions, private status, Islamic style. Students studying in these three madrasahs come from various cities in Indonesia, especially students of MA NU Banat, MA TBS, and the last MA Qudsiyah.

From the background of the phenomenon of the implementation of education in madrasah above, the authors are interested to conduct research on the leadership of the head of madrasah. How does the leadership of the head of madrasah build communication with madrasah stakeholders?

\footnotetext{
${ }^{5}$ Ibid., 39.
} 


\section{B. Discussion}

\section{The Leadership of The Head of Madrasah in Building Communication with Madrasah Stakeholders}

The findings of research on the leadership of the head of madrasah in establishing communication with sakeholders are: (a) establishing cooperation relationship with stakeholders element; (b) structured silaturrahim; (c) becoming motor of change of progress of madrasah; (d) spiritual orientation and social capital to achieve financial and human capital; (e) together work based on the principle of expediency; (f) taboo to discuss about salary and position and embarrassment show property and property ownership; (g) position is trust and not purpose; (h) firmly in giving sanction; (i) supervision of madrasah culture background; (j) time and work discipline; (k) build relationships with graduates through programmed activities.

The research findings mentioned above can be formulated into: First, the leadership of the head of MA TBS build relationships with students, electric educators, and the community is very intense, close, humanist, able to be exemplary, to be mediated, far from degrading manner, resolute in attitude. It's just that leadership in the institution is less attention to leadership regeneration. The head of madrasah occupies the post of madrasah no less than 3-4 years. The relationship between the head of madrasah and the students who are all male students is the relationship as between kiai and santri. The role profile of kiai in the head of madrasah is more dominant than the position of the head of madrasah as principal. All of these madrasah students are male and wherever they are should wear the pecis. If there is 
a student let alone ustaz who does not wear pecis and known to the madrasah, then the concerned will receive sanctions.

Second, the leadership of the head of MA Qudsiyah in building communication with stakeholders is less proportionate. This madrasah with the typology of pesantren salafiyah, so that the communication is built well to students, to the educators and education and to the community patterned pesantren. All the students here are the men with the main attribute being the black pecis. This madrasah relationship with religious leaders in Kudus takes precedence. The popularity of this madrasah in the sanctuary and its surroundings is due to the learning in this madrasah supported by the main kiai in the center of Menara Kudus. So for the community, studying in Qudsiyah will gain the blessings of knowledge from the kiai in Kudus. Relations with relevant agencies, especially the Ministry of Religious Affairs less than the maximum. This MA Qudsiyah is very old, first established in the Dutch colonial period. But only the last 11 years of this institution under the guidance of the Ministry of Religious Affairs, due to the national final examination policy.

Third, the leadership of the head of MA NU Banat in building communication with stakeholders through various activities and forums that have been structured. Discipline in disciplining students and teachers and administrative staff indiscriminately. This institution coordinates actively with the government through Ministry of Religious Affairs and other agencies including the Ministry of Education and Culture in accordance with the needs, especially related to the quality competition between schools. MA NU Banat is supported by religious leaders and scholars in Kudus. There are regular forums both structurally and culturally that bring together these institutions with religious leaders in the community in order to cooperate for better service quality improvement. 


\section{Leadership Communication with Madrasah Stakehoders}

From the exposure of the research data of the three madrasahs on the leadership of the head of madrasah in building relationships with stakeholders, raises the following questions.

a. Why should the head of madrasah be a facilitator and mediator if there is a conflict or misunderstanding among the madrasah stakeholders?

A leader in an educational institution should not place himself in a group and fight with other groups that are still in one institution. Conflict of interest in an institution is still seen as a natural thing and is seen as a dynamics of the institution, as long as the conflict does not lead to disruption of the order of education. Interpersonal communication between fellow teachers and employees is not upset. Conflict within the organization is actually a form of not yet meeting the same understanding of a problem from a different point of view. Misunderstanding between stakeholders in educational institutions if not managed or addressed properly is potentially will disrupt the disintegration of the organization.

Leaders in such situations play an important role in communicating and seeking a more equitable, open and proportional solution of the disputing parties. Instead, the leader is caught up in one group, as has been happening here and there. The difference of viewpoints in advancing the institution is common, even that distinction has become the law of nature, and in the context of the Sunnah of Prophet Muhammad saw. the difference of ummah is mercy which becomes life becomes dynamic and full of color and rich 
repertoire of thought. Leaders are required to take a position in the middle and must create justice for all the subordinates and reconcile the subordinates if there is conflict or even conflict. Sunnah, based leadership of Prophet Muhammad saw., requires a leader to be a islah interpreter (peace). This is because a leader is elected, inaugurated by all members of the institution because of his excess, his emotional maturity, his wisdom and point of view far above the abilities of most people.

\section{b. Why should the position of the head of madrasah not be required without going through a credible and transparent procedure?}

The head of MA TBS and MA Qudsiyah occupy the post of the head of madrasah is not like a kiai who occupies the role of kiai in a boarding school. Never happened in the tradition of boarding school, a kiai suddenly replaced before kiai caregiver is elderly due to illness or due to death. This is different from the MA NU Banat which has followed the mechanism and procedures for the appointment and dismissal of the head of madrasah as prevailing in formal schools in general. Although MA NU Banat in the three previous periods ever had a change of leadership as applicable in the tradition of pesantren.

In the tradition of madrasah leadership based on pesantren, the leader is a sacred duty and a noble task in carrying out the mandate of the people who are only special people who are capable of carrying out the task of leadership. The leader is the representative of God on earth who carries the great task of participating in preserving and preserving the living order of man and nature to remain balanced, harmonious, full of beauty, and away from conflict and war and bloodshed. Instead, leaders came to beat the drums of war among members of the organization. There 
is no concept of nominating exchanges in the process of selecting a leader as is commonplace. No one who signed up to be a leader let alone ambitious. The concept of leadership of Prophet Muhammad saw. did not know buying voters votes to choose people who have chosen him to be a leader let alone to justify all the ways to become a leader. The leadership of the Prophet Muhammad saw. did not know kidnap abduction, brawl, and even murder for the sake of someone sitting in the office, except after the death of Prophet Muhammad saw.

The procedure of registering to be a leader on the pretext of democracy, sportsmanship, and other defensive attitudes is highly unjustified if the fact to get the most votes is purchased at a high cost. Being a real leader is very heavy, even the body and the family must be ready to be sacrificed for the life of the better people. Asking to be a leader, issuing material capital, buying votes, being elected leader (then serving) then corruption is not a leadership in Islam.

The election mechanism by registering with certain conditions is fair and still proportional, therefore all of them are only administrative technical purposes which aim to regulate the election order of who is the candidate for leadership. The leader of an institution is entirely left to the people who will vote. If it is necessary and able to vote who is the leader is based on agreement, if the community he leads is not too much like a madrasah education institution. Direct or indirect election in a democratic and autocratic system is not essential if the substance of the objective of leadership has been able to create a sense of justice and the development of a well-born and inhabited community of people who are pious. Therefore asking to be a leader is cursed by the leadership of the Prophet Muhammad saw. 
as narrated by Imam Muslim in the book of hadits Shabih Muslim, namely:

Do not ask for a position, because if you are given without asking then you will get help and if you are given because of the request, then you will find it difficult. ${ }^{6}$

\section{c. Why should the leadership of the head of madrasah in madrasah finance management be accountable and transparent?}

Leadership based on Islamic syari'ah strongly condemns corruption and gratification. Corruption is simply instigated as an act of enriching themselves and the family by breaking the law. Acts of corruption are only committed by persons who have power and authority in using the budget of the institution. Without power, one can not do corruption. The higher the level of a person's power, the greater the impact of his corrupt actions on people's lives.

Many factors cause officials or leaders to commit acts of corruption and against the law. Initially there was a hypothesis that the corrupt acts committed by public leaders were due to a lack of salary and income, so his salary was increased. The cause of corruption is due to the supervision of public officials who are not effective and also because of the weakness of the law enforcement apparatus. Therefore, for the sake of the leaders not corruption, the system of supervision and legal system must be improved. But the act of corruption has become a culture of society that keeps corruption is an economic activity to gain financial benefits by against the law. Corruption acts one of them is because the system values that have been shifted and changed. Corruption is no more a part of the normal act of generating economic income. Shame and abject as a

\footnotetext{
${ }^{6}$ Muslim bin al-Hajjaj, Shahih Muslim (Beirut: Dar al-Fikr, 2006).
} 
leader who purchased corruption was slowly only one's viewpoint. Staying from the point of ideology where the act of corruption is seen. Causes of corruption seen from the point of view of values (moral-ethical values) this is the educational practitioners do self-introspection. There is a potential mistake in applying the educational paradigm in Indonesia. This is where there are opportunities where the supra and infra structure of education in Indonesia are being reorganized. Some societies claim that one that creates corruption is an imprecise educational ideology. This lack of ideology is supposed to have given birth to intellectuals in their field but has a corrupt mentality.

Madrasah Aliyah (MA) as a religious institution has the opportunity to take part in improving the life of nation and state by one of them is to organize madrasah education leadership based on Islamic syari'ah, that is for the commitment not to commit any illegal act, that is corruption. The property or other form of wealth acquired by acts of corruption is not bringing barokah (not benefits). The simple indicator of the unbellowed property is to result in an uneasy life accompanied by life problems that have no way of escape. Prophet Muhammad saw. has asserted in the book of hadith narrated by Ibnu Hiban below:

Explain the obligation of a leader to not have the ambition of pouring treasures to enrich themselves. ${ }^{7}$

It is narrated also in other parts of the unfavorable property gathered by corrupt leaders:

Explain the obligation of a leader not to take property except properly to make the treasure a blessing. ${ }^{8}$

${ }^{7}$ Muhammad bin Hibban bin Ahmad Hibban bin Muadz bin Ma'bad at-Tamimi Abu Hatim ad-Darimi, Shabih Ibn Hibban bi Tartib Ibni Baliba (Beirut: Mu'assasah ar-Risalah, 1993).

${ }^{8}$ Ibid. 
Narrated by Imam Bukhari about the simple lifestyle of a world leader like Prophet Muhammad saw. and also his friend, Umar bin Khattab. They meet the needs of camel vehicles and self and family needs from their own money and not with institutional or government facilities. This is indeed an ideal uswah leadership. The Prophet Muhammad's leadership strives for the prosperity of the people and not the other way around, ie leaders who seek wealth amidst the suffering and misery of the ummah as it has been so far. Prophet Muhammad saw. said:

A leader buys his household needs with his personal money and says Umar that the Prophet Muhammad saw. bought a camel from Umar and Ibnu Umar bought a camel for himself. Said Abdurrahman bin Abi Bakr that came a polytheist carrying goats and bought the Prophet, the Prophet also bought camel from Jabir. ${ }^{9}$

Instead of stealing agency money, even asking how much the salary from the teacher is something that is taboo and against tradition. This is the case with the practice of MA NU Banat, MA NU Qudsiyah, and MA Salafiyah TBS. Even some teachers until their salary (bisyarah) still there how many months never asked. Leadership in Islam teaches that teaching is a work of humanity, which must be based on awareness of dedication, sincerity and doing the best for students (professional). Economic life (ma'isyah) is another matter. Most of the seniors managing the madrasah are private entrepreneurs. It is really inculcated in every individual teachers that teaching should be sincere, professional, and God will provide a wide and bourgeois life and sustenance way. This is the belief of teachers in the Sunnah based leadership of Prophet Muhammad saw. The disciples also

${ }^{9}$ Abu Abdillah bin Ismail al-Bukhari, al-Jami' al-Musnad ash-Shahih alMukbtashar min Umuri Rasulillah saw. wa Sunanubu wa Ayyamubu (Lebanon: Dar Thauq an-Najah, $1422 \mathrm{H}$ ). 
get counseling by the teachers that the study of discarded ignorance and weakness is a duty. The idiosyncrasies that studying to become rich and successful are far from the minds of the students and their families. The student's duty is to learn real and to develop talents and skills.

Sustenance came through working into what and how much is the divine domain not the realm of human beings. Our duty is to work and work, learn and learn to be the best. This is the ideology instilled in the students. Because indeed half the future of life is mysterious. Man can not fully control and control the future. Waiting for a good future to come alone is also impossible. This is the equilibrium of thinking that keeps people from stress and is not dependent on logical-mathematical calculations. Leadership ideology that teaches the spirit of devotion and sincerity above is really implanted in the big family of madrasah so it is expected in the future of its students if the official does not have a corrupt mentality and does not accumulate wealth even by breaking the law.

Other diseases that attack leaders and holders of power in all institutions receive bribes on an intent desired by certain parties in violation of law and ethics. In the context of the provision of education, bribery is usually done by parents in rogue so that children can be accepted at a particular school or for their child to graduate with high scores on a test moment. The employees or officials who receive bribes are categorized as demand-side corruption. In practice, the giver and bribe processors are processed in law.

Islmai's leadership is very inconsiderate of dishonest acts, both bribes (ar-rasyi) and those who accept bribes (almurtasyi) are cursed by Allah in the context of Islam. But regardless of any context, in any universal ethics, bribing and accepting bribes is a fraudulent and unsporting act, violating 
a sense of justice. Now many cases in legal institutions, where the practice of bribery is a common crime of the parties to pass the case in order to be free from lawsuits. Prophet Muhammad saw. asserted in the book of hadith narrated by Ibnu Majah, as below:

Allah cursed the bribers and the recipients of bribes. ${ }^{10}$

\section{d. Why should the head of madrasah be able to communicate to educators and education personnel?}

Communicating is exchanging thoughts and feelings for conveying ideas and ideas. The head of madrasah is required to have the art of communicating in accordance with the cultural background of madrasah. Teachers and education personnel need communication with the head of madrasah who is expected to be able to listen to all the problems and expectations of his subordinates. The organization will be great with strong leadership. No exception educational organizations such as madrasah. Madrasah is a formal educational institution that is characterized by religion to provide educational services with the vision of manifesting the ideal human, healthy inward, master of science, able to build life in society and character of Indonesian and oriented to get success in the world and the hereafter. To realize these ideals needed a strong leadership foundation. Leadership built on the personal foundation of a strong leader of mature personality, intelligent in thinking, forward-oriented, and able to issue complex problems facing the organization. Therefore, the head of madrasah as an educational leader, as exemplified by the Prophet Muhmmad saw., is required to have a strong leadership character, namely: (1) giving priority

${ }^{10}$ Abu Abdillah Muhammad bin Yazid bin Majah al-Qazwini, Sunan Ibnu Majab (Lebanon: Dar Ihya al-Kutub al-'Arabiyyah, n.d.). 
function as the foundation in choosing people or something, not appearance or other external factors; (2) give priority to benefits rather than futility; (3) precedence is more urgent than can be postponed; (4) he is more concerned with others than himself; (5) he chose the path that was hard for him and the easiest for his people; (6) he prefers the purpose of the hereafter rather than the worldly intent.

\section{e. Why should the madrasah head communicate and coordinate with the madrasah community?}

One of the principles of leadership in Islam is trust in those who carry out leadership tasks. Madrasah have a tradition of silaturrabim through the channels of cultural institutions. Silaturrahim aims at institutional management in the context referred to as coordination. Leadership requires the cooperation of various people working in an institution. Each component performs its function and works. Even coordination is the key to the success of various educational programs. A leader in addition to regulating the coordination must also provide full confidence to the educators and educational personnel in carrying out the functions of educational institutions. Teachers and administrative staff will feel appreciated by the leadership of the madrasah and also the opposite. All will work hard with all the ability that he has to run the mandate that has been given to him. One of the tasks of the head of madrasah is to provide motor and motion functions for all the subordinates in carrying out their duties and mandates.

This corresponds to that proposed by Shelton it identifies a cation that one is in the competence of leadership competencies interaction with subordinates. ${ }^{11}$ In the relations of leaders and followers, he emphasizes how they should

${ }^{11}$ Ken Shelton (ed.), A New Paradigm of Leadership, transl. Oka (Jakarta: Elex Media Komputindo, 2002). 
interact. This confirms that good leadership requires unselfish leadership qualities. In addition, leaders and followers are two sides of the same process. In the relationship of the soul of leadership, some observers enter the spiritual realm. Other series of qualities that colored include the heart, soul, and morals. Leadership is not an intellectual issue or an introduction, but an emotional one. Leadership of head of formal institutions, both educational institutions, especially non-educational institutions that have failed in carrying out their leadership functions, because one of them does not have a complete emotional and spiritual quality.

\section{Conclution}

Based on the discussion it can be concluded that the leadership of the head of madrasah communication with the stakeholders is communication is the main function in the leadership of the head of madrasah's communication built and maintained in accordance with the culture through the cultural institution of integrity and the authority of a madrasah leader. It becomes the main factor in building trust stakeholders interests of the spiritual life quality of all madrasah communities is capital in achieving human capital and economic life (economc capital) institutional coordination. It is packed with personal and group silaturrabim building the culture of spiritual leadership, which means that the position is amanah divine that all the consequences of the office are handed over and lean only because and for Allah alone. 


\section{REFERENCE}

al-Bukhari, Abu Abdillah bin Ismail. al-Jami' al-Musnad ash-

Shabih al-Mukhtashar min Umuri Rasulillah saw. wa

Sunanubu wa Ayyamubu. Lebanon: Dar Thauq anNajah, $1422 \mathrm{H}$.

ad-Darimi, Muhammad bin Hibban bin Ahmad Hibban bin

Muadz bin Ma'bad at-Tamimi Abu Hatim. Shabih Ibn

Hibban bi Tartib Ibni Baliba. Beirut: Mu'assasah arRisalah, 1993.

al-Hajjaj, Muslim. Shahih Muslim. Beirut: Dar al-Fikr, 2006.

Komariah, A. and T. Cepi. Visionary Leadership: Menuju Sekolah Efektif. Jakarta: Bumi Aksara, 2005.

Mulyadi. Kepemimpinan Kepala Madrasah dalam Mengembangkan Budaya Mutu. Jakarta: Badan Litbang dan Diklat Kementerian Agama RI, 2010.

Mulyasa. Manajemen dan Kepemimpinan Kepala Madrasah. Jakarta: Bumi Aksara, 2002.

al-Qazwini, Abu Abdillah Muhammad bin Yazid bin Majah.

Sunan Ibnu Majah. Lebanon: Dar Ihya al-Kutub al'Arabiyyah, n.d.

Shelton, Ken (ed.). A New Paradigm of Leadership, transl. Oka. Jakarta: Elex Media Komputindo, 2002.

Undang-Undang Republik Indonesia Nomor 20 Tahun 2003 Tentang Sistem Pendidikan Nasional, http:// www.hukum.unsrat.ac.id, PDF, accessed at Oktober 14, 2013. 